\title{
Bergenia pacumbis from Nepal, an astonishing enzymes inhibitor
}

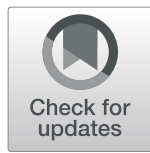

Bishnu Prasad Pandey ${ }^{1^{*}}$ (D) Suman Prakash Pradhan ${ }^{1}$, Kapil Adhikari ${ }^{1}$ and Saroj Nepal ${ }^{2}$

\begin{abstract}
Background: The Bergenia species are perennial herbs native to central Asia, and one of the most promising medicinal plants of the family Saxifragaceae which are popularly known as 'Pashanbheda'. The aim of this study was to evaluate antioxidant and $a$-amylase, $a$-glucosidase, lipase, tyrosinase, elastase, and cholinesterases inhibition potential of Bergenia pacumbis of Nepali origin collected from the Karnali region of Nepal.

Methods: The sequential crude extracts were made in hexane, ethyl acetate, methanol, and water. Antioxidant activities were analyzed by 2,2-diphenyl-1-picrylhydrazyl (DPPH) and 2,2'-azino-bis (3-ethylbenzothiazoline-6-sulfonic acid) (ABTS) assay. The $a$-amylase, $a$-glucosidase, lipase, tyrosinase, elastase, acetylcholinesterase, and butyrylcholinesterase inhibition were analyzed by the 3,5-Dinitrosalicylic acid (DNSA), p-Nitrophenyl-a-Dglucopyranoside (p-NPG), 4-nitrophenyl butyrate (p-NPB), I-3,4-dihydroxyphenylalanine (L-DOPA), N-Succinyl-Ala-Alap-nitroanilide (AAAPVN), acetylthiocholine, and butyrylcholine as a respective substrate. The major metabolites were identified by high performance liquid chromatography with electron spray ionization- quadrupole time-of-flight mass spectrometry (HPLC-ESI-QTOF-MS) profiling.

Results: Our results revealed the great antioxidant ability of crude extract of $B$. pacumbis in ethyl acetate extract against both DPPH $\left(I C_{50}=30.14 \pm 0.14 \mu \mathrm{g} / \mathrm{mL}\right)$ and $A B T S\left(I C_{50}=17.38 \pm 1.12 \mu \mathrm{g} / \mathrm{mL}\right)$. However, the crude methanol extract of $B$. pacumbis showed the comparable enzymes inhibitions with standard drugs; $a$-amylase $\left(I_{50}=14.03 \pm\right.$ $0.04 \mu \mathrm{g} / \mathrm{mL})$, $a$-glucosidase $\left(I C_{50}=0.29 \pm 0.00 \mu \mathrm{g} / \mathrm{mL}\right)$, lipase $\left(I C_{50}=67.26 \pm 0.17 \mu \mathrm{g} / \mathrm{mL}\right)$, tyrosinase $\left(I C_{50}=58.25 \pm\right.$ $1.63 \mu \mathrm{g} / \mathrm{mL})$, elastase $\left(I C_{50}=74.00 \pm 3.03 \mu \mathrm{g} / \mathrm{mL}\right)$, acetylcholinesterase $\left({ } C_{50}=31.52 \pm 0.58 \mu \mathrm{g} / \mathrm{mL}\right)$, and butyrylcholinesterase $\left(\mathrm{IC}_{50}=11.69 \pm 0.14 \mu \mathrm{g} / \mathrm{mL}\right)$. On the basis of HPLC-ESI-QTOF-MS profiling of metabolites, we identified major compounds such as Bergenin, Catechin, Arbutin, Gallic acid, Protocatechuic acid, Syringic acid, Hyperoside, Afzelechin, Methyl gallate, Paashaanolactone, Astilbin, Quercetin, Kaempferol-7-O-glucoside, Diosmetin, Phloretin, and Morin in methanol extract which has reported beneficial bioactivities.

Conclusion: Our study provides a plethora of scientific evidence that the crude extracts of B. pacumbis from Nepalese origin in different extracting solvents have shown significant potential on inhibiting free radicals as well as enzymes involved in digestion, skin related problems, and neurological disorders compared with the commercially available drugs.
\end{abstract}

Keywords: Bergenia pacumbis, Antioxidant, Enzyme inhibition, Major metabolites, HRMS

\footnotetext{
* Correspondence: bishnu@ku.edu.np

'Department of Chemical Science and Engineering, Kathmandu University,

PO Box No. 6250, Dhulikhel, Kavre, Nepal

Full list of author information is available at the end of the article
}

\section{$\triangle B M C$}

(c) The Author(s). 2020 Open Access This article is licensed under a Creative Commons Attribution 4.0 International License, which permits use, sharing, adaptation, distribution and reproduction in any medium or format, as long as you give appropriate credit to the original author(s) and the source, provide a link to the Creative Commons licence, and indicate if changes were made. The images or other third party material in this article are included in the article's Creative Commons licence, unless indicated otherwise in a credit line to the material. If material is not included in the article's Creative Commons licence and your intended use is not permitted by statutory regulation or exceeds the permitted use, you will need to obtain permission directly from the copyright holder. To view a copy of this licence, visit http://creativecommons.org/licenses/by/4.0/ The Creative Commons Public Domain Dedication waiver (http://creativecommons.org/publicdomain/zero/1.0/) applies to the data made available in this article, unless otherwise stated in a credit line to the data. 


\section{Background}

The Bergenia species are perennial herbs native to central Asia, and one of the most promising medicinal plants of the family Saxifragaceae which are commonly known as 'Pashanbheda'. Because of anti-lithiatic and diuretic activities, different species of Bergenia are used to treat kidney and urinary bladder stones and root powder is used to cure diarrhea, dysentery, thirst, vomiting, and indigestion in traditional medicine practice in Nepal, India, and China $[1,2]$. Numerous pharmacological activities such as antipyretic, antioxidant, antilithiatic, antiplasmodial, antitussive, antiulcer, antidiabetic, hepatoprotective, hemorrhoidal, analgesic, insecticidal, anti-inflammatory, antimicrobial, and diuretic properties have been reported in different species of Bergenia [3-6]. Although a variety of secondary metabolites have been identified from different parts of Bergenia species [6, 7], the major bioactive phenolics compounds mainly concentrated in their roots; bergenin, arbutin, and gallic acid, are principal contributor of the therapeutic properties of Bergenia species [8-10] that leads to variation in their medicinal activities.

Diabetes mellitus (DM) is a life-threatening metabolic disorder characterized by chronic hyperglycemia resulting from defects in insulin secretion, insulin action, or both [11, 12]. Alpha-glucosidase and alpha-amylase are the important enzymes involved in the digestion of carbohydrates; $\alpha$-amylase is involved in the breakdown of long-chain carbohydrates and $\alpha$-glucosidase breaks down starch and disaccharides to glucose and helps in intestinal absorption $[13,14]$. The $\alpha$-amylase and $\alpha$-glucosidase inhibitors help to reduce the rate of digestion of carbohydrates and thus type 2 diabetes mellitus (T2DM) complications [15]. On the other hand, an uneven accumulation of fat through the disproportion intake of calories and their utilization results in obesity which is becoming a major public health concern [16]. In the present context, the complex interactions of genetic, behavior, and surrounding environment with economic and social status and lifestyles of human beings are responsible for the up surging of T2DM complications $[17,18]$. Moreover, obesity enables the development of different metabolic disorders such as diabetes, hypertension, and cardiovascular diseases [19-21]. Suppressing the absorption of dietary lipids in the gastrointestinal tract is one of the best option to overcome the obesity problems which can be accomplished by inhibiting pancreatic lipase enzyme that is responsible for the digestion of fats consumed in the regular diets [22, 23].

Although, melanin can protect tissues from oxidative and chemical stress [24], the excessive production of melanin causes various skin related problems. Melanin biosynthesis occurs in the melanocytes through a series of enzymatic and chemical reactions. Tyrosinase is a coppercontaining monooxygenase that is widely distributed in microorganisms, animals, and plants which contribute to the melanin synthesis pathways [25]. Tyrosinase is frequently used in cosmetic and food industries as an antibrowning agent [26]. However, a high amount of tyrosinase might leads to hyper melanogenesis. Elastase is a primary enzyme responsible for the breakdown of elastin, which has unique elastic recoil properties and vital for giving elasticity to the skin [27-29] and other extracellular matrices (ECM) proteins which are responsible for providing support, segregating tissues from one another, cell migration, gene expression, and regulating intercellular communication [29, 30]. Finding inhibitors of tyrosinase and elastase enzymes can be useful to prevent skin pigmentation and loss of skin elasticity which works as skin whitening and anti-aging agents correspondingly.

Alzheimer's disease (AD) is characterized by the loss of cholinergic neurons that alters the brain activity and cause cognitive impairment which is mainly caused by the progressive reduction of acetylcholine. Thus, inhibition of acetylcholinesterase and butyrylcholinesterase has been considered as a potential target in the treatment of $\mathrm{AD}$ [31]. To the best of our knowledge, no such investigation of the biochemical activity of B. pacumbis has been carried out to date. In this study, we focused on the profiling of major metabolite constituents and reported the in-vitro enzymes inhibition activity of Bergenia pacumbis (Buch.Ham. ex D. Don) C.Y. Wu \& J.T. Pan of Nepalese origin collected from the Karnali region of Nepal in the different solvent extracts for the first time which are beneficial in gaining scientific evidence in curing the negative health impacts of daily life-threatening enzymes; $\alpha$-amylase, $\alpha$ glucosidase, and lipase that involved in digestion, tyrosinase and elastase that involved in skin related problems, and acetylcholinesterase and butyrylcholinesterase that involved in neurological disorders.

\section{Methods \\ Chemicals used}

Different chemicals reagents used in this study were purchased from different chemical suppliers. Quercetin, 2, 2Diphenyl-1-picrylhydrazyl (DPPH) and 2, 2'-Azino-bis (3ethylbenzothiazoline-6-sulfonic acid) diammonium salt (ABTS), $\alpha$-amylase from procine pancreas (Type VI-B), Tyrosinase from mushroom, Lipase from procine pancreas (Type II), 4-nitrophenyl butyrate (p-NPB), Orlistat, Acarbose, $\alpha$-glucosidase from Saccharomyces cerevisiae (Type-I), p-Nitrophenyl- $\alpha-D$-glucopyranoside (p-NPG), Sodium carbonate, Kojic acid, 1-3,4-dihydroxyphenylalanine (L-DOPA), N-Succinyl-Ala-Ala-p-nitroanilide (AAAPVN), Porcine pancreatic elastase (PPE), Galantamine, Acetylcholinesterase (AChE), Butyrylcholinesterase (BChE), Acetylcholine iodide, Butyrylcholine iodide, 5,5'-dithiobis-(2-nitrobenzoic acid) (DTNB), Acetonitrile (LC-MS grade), Methanol (LCMS grade), Formic acid (analytical grade), and Acarbose 
from Sigma-aldrich (USA). The 3,5-Dinitrosalicylic acid (DNSA) from HIMEDIA (India) and Sodium-potassium tartrate from Merc (Germany). Methanol, Sodium Hydroxide, Dimethyl sulfoxide (DMSO), and Starch from Fisher Scientific (India). Aluminum Chloride, Hexane and Gallic Acid from LOBA Chemie (India).

\section{Plant collection and authorization}

The plant and its rhizomes were collected from Rimi village of Chankheli Rural municipality, Humla District, Karnali Province of Nepal $\left(29^{\circ} 07^{\prime} 52^{\prime \prime N}\right.$ and $\left.82^{\circ} 30^{\prime} 50^{\prime \prime} \mathrm{E}\right)$ in August 2018 and identified in Nepal National Herbarium and Plant Laboratory (KATH) Godhawori, Lalitpur, Nepal with reference letter number of 2074/2075-230.

\section{Sample preparation}

The collected plant sample was dried at room temperature and made powdered by grinding in an electrical grinder. The crude extract of $B$. pacumbis was extracted in hexane-ethyl acetate-methanol-water system where extracts dependent on the polarity of the solvent, the chemical nature of the extracted compound, the plant matrix, and presence of interfering substances. Ten-gram powder sample was macerated in $100 \mathrm{~mL}$ of hexane and kept overnight on a shaker at $150 \mathrm{rpm}$ at room temperature. On the next day, the entire mixture was filtrated and collected. The residue was further sequentially extracted with ethyl acetate, methanol, and water successively. The filtrated of each fraction were concentrated to dryness by evaporating on vacuum evaporator (hanil Modul 4080C). The extracted crude samples were kept in an airtight glass vial and stored at $4{ }^{\circ} \mathrm{C}$ until use.

\section{Antioxidant activities DPPH assay}

In-vitro antioxidant potential of the different extracts of $B$. pacumbis was assessed by 1,1-diphenyl 1-2-picryl-hydrazyl (DPPH) assay accordingly with Jha et al. [32]. One milliliter of plant extract of different concentrations was added in $3 \mathrm{~mL}$ of the DPPH solution $(100 \mathrm{mM})$ and incubated for $30 \mathrm{~min}$ in the dark. Absorbance was measured at the wavelength $(\lambda)=517 \mathrm{~nm}$ in a UV-visible spectrophotometer (UV-1800, SHIMADZU). Gallic acid and methanolic DPPH were used as reference and positive control respectively. The following formula was used to calculate percentage of radical scavenging (\%RSA).

$$
\% \mathrm{RSA}=\frac{\text { Absorbance of Control-Absorbance of Test }}{\text { Absorbance of Control }} * 100 \%
$$

\section{ABTS assay}

In-vitro 2, 2' -azino-bis (3-ethylbenzothiazoline-6-sulphonic acid) (ABTS) scavenging assay was performed as by Liyanaarachchi et al. [33]. An aliquot of $1 \mathrm{~mL}$ of plant extract of varying concentrations was mixed with $3 \mathrm{~mL}$ of ABTS working solution and incubated for $10 \mathrm{~min}$ in the dark and the decrease in absorbance was recorded at $\lambda=$ $720 \mathrm{~nm}$ in a UV-visible spectrophotometer. Gallic acid and $50 \%$ methanol were used as reference and positive control respectively. The percentage of ABTS scavenging was determined by the following formula.

$$
\% \mathrm{RSA}=\frac{\text { Absorbance of Control-Absorbance of Test }}{\text { Absorbance of Control }} * 100 \%
$$

\section{Alpha-amylase inhibition activity}

The DNSA method was used to determine $\alpha$-amylase inhibition activity with a slight modified procedure of Wickramaratne et al. [34]. Briefly, $200 \mu \mathrm{L}$ plant extract of varying concentrations and $200 \mu \mathrm{L} 3 \mathrm{unit} / \mathrm{mL} \alpha$ amylase were mixed and incubated for $15 \mathrm{~min}$ at $37^{\circ} \mathrm{C}$. Two hundred microliter of $1 \%$ starch solution was added on it and further incubated for the next $5 \mathrm{~min}$ at $37^{\circ} \mathrm{C}$, then $200 \mu \mathrm{L}$ of DNSA solution was added on it and heated for $10 \mathrm{~min}$ at $90-95^{\circ} \mathrm{C}$ in order to terminate the reaction and the final volume was adjusted to $5 \mathrm{~mL}$ by the addition of distilled water. The absorbance was measured at $\lambda=540 \mathrm{~nm}$ in a UV-visible spectrophotometer. $1 \%$ DMSO and Acarbose were used as positive control and reference respectively. The following formula was used to calculate the percentage of $\alpha$-amylase inhibition.

$$
\% \alpha \text {-amylase inhibition }=\frac{\text { Absorbance of Control-Absorbance of Test }}{\text { Absorbance of Control }} * 100 \%
$$

\section{Alpha-glucosidase inhibition activity}

The $\alpha$-glucosidase inhibitory activity was measured by using $\mathrm{p}-\mathrm{NPG}$ as a substrate with a modified method from Elbashir et al. 2018 [12]. Briefly, $10 \mu \mathrm{L}$ of the sample solution with varying concentrations were mixed with $60 \mu \mathrm{L}$ of phosphate buffer $(0.2 \mathrm{M} \mathrm{pH} 6.8)$ and $10 \mu \mathrm{L}$ of $\alpha$-glucosidase $(1 \mathrm{U} / \mathrm{mL})$ in phosphate buffer and incubated for $5 \mathrm{~min} 37^{\circ} \mathrm{C} .20 \mu \mathrm{L}$ of p-NPG $(4 \mathrm{mM})$ was added to the mixture and incubated further for $12 \mathrm{~min}$ and the absorbance was measured at $\lambda=405 \mathrm{~nm}$ in a UV-visible spectrophotometer. 1\% DMSO and Acarbose were used as positive control and reference respectively. The percentage inhibition of $\alpha$-glucosidase was calculated as follows.

$$
\% \alpha \text {-glucosidase Inhibition }=\frac{\text { Absorbance of Control }- \text { Absorbance of Test }}{\text { Absorbance of Control }} * 100 \%
$$

\section{Lipase inhibition activity}

The inhibitory potential against lipase was determined by using p-NPB as a substrate [35]. The lipase enzyme was prepared in $0.1 \mathrm{M}$ phosphate buffer saline, $\mathrm{pH} 8.0$ and $\mathrm{p}-\mathrm{NPB}$ was prepared in $0.1 \mathrm{mM}$ in ethanol. In brief, 
different concentrations of plant extracts were mixed with $50 \mu \mathrm{g} / \mathrm{mL}$ of the lipase enzyme and incubated for $15 \mathrm{~min}$ at $37^{\circ} \mathrm{C} .10 \mu \mathrm{L}$ of $\mathrm{p}-\mathrm{NPB}$ was added and the reaction volume was maintained to $2 \mathrm{~mL}$ with the addition of phosphate buffer and proceeded for $15 \mathrm{~min}$ of additional incubation at $37^{\circ} \mathrm{C}$. The absorbance was measured at $\lambda=405 \mathrm{~nm}$ in a UV-visible spectrophotometer. $1 \%$ DMSO and Orlistat were used as positive control and reference respectively. The percentage inhibition of lipase was calculated as follows.

\%Lipase Inhibition $=\frac{\text { Absorbance of Control }- \text { Absorbance of Test }}{\text { Absorbance of Control }} * 100 \%$

\section{Tyrosinase inhibition activity}

L-DOPA substrate was used to determine tyrosinase ihibition activity, accordingly with the procedure followed by Petrillo et al. [36] with slide modifications. In brief, plant extract of different concentrations in potassium phosphate buffer $(0.05 \mathrm{M}, \mathrm{pH} 6.5)$ were mixed with $20 \mu \mathrm{L}$ of mushroom tyrosinase $(1000 \mathrm{U} / \mathrm{mL})$ and incubated at $27^{\circ} \mathrm{C}$ for $10 \mathrm{~min}$. Then, $200 \mu \mathrm{L}$ of L-DOPA (5 $\mathrm{mM}$ ) was added to the mixture and the reaction value was maintained to $2 \mathrm{~mL}$ by the addition of phosphate buffer and incubated further for $30 \mathrm{~min}$. Absorbance was measured at $\lambda=492 \mathrm{~nm}$ in a UV-visible spectrophotometer. The phosphate buffer and Kojic acid were used as positive control and reference respectively. The percentage of tyrosinase inhibition was calculated as follows.

$\%$ Tyrosinase Inhibition $=\frac{\text { Absorbance of Control }- \text { Absorbance of Test }}{\text { Absorbance of Control }} * 100 \%$

\section{Elastase inhibition activity}

AAAPVN substrate was used to determine elastase inhibition activity, accordingly with the procedure of Liyanaarachchi et al. [33] with slight modification. In brief, the plant extracts of different concentrations were incubated with PPE $(0.05 \mathrm{U} / \mathrm{mL})$ for $20 \mathrm{~min}$ and $50 \mu \mathrm{g} / \mathrm{mL}$ AAAPVN was added to the reaction mixture and proceeded for $30 \mathrm{~min}$ of additional incubation at $25^{\circ} \mathrm{C}$. The final reaction volume was maintained to $200 \mu \mathrm{L}$ with the addition of $0.2 \mathrm{M}$ Tris-HCL buffer ( $\mathrm{pH}$ 8.0). The absorbance was taken in $\lambda=410 \mathrm{~nm}$ in a 96 -microplate reader (BioTek, EPOCH). 1\% DMSO and Quercetin were used as positive control and reference. The percentage of elastase inhibition was calculated as follows.

$$
\text { \%Elastase Inhibition }=\frac{\text { Absorbance of Control-Absorbance of Test }}{\text { Absorbance of Control }} * 100 \%
$$

\section{Cholinesterase inhibition activity}

Acetylcholinesterase (AChE) and butyrylcholinesterase (BChE) inhibition assays were performed accordingly with Samaradivakara et al. [37] with some modifications. At first, $0.05 \mathrm{U} / \mathrm{mL}$ of AChE or $0.5 \mathrm{U} / \mathrm{mL}$ of $\mathrm{BChE}$, and plant extract of different concentrations were mixed and incubated at $25^{\circ} \mathrm{C}$ for $15 \mathrm{~min}$. Then, $1 \mathrm{mM}$ acetylthiocholine iodide or $1.5 \mathrm{mM}$ of butyrylcholine iodide and $0.5 \mathrm{mM}$ DNTB were added to the reaction mixture followed by an additional $10 \mathrm{~min}$ of incubation. The total reaction volume was maintained to $200 \mu \mathrm{L}$ by the addition of $0.1 \mathrm{M}$ sodium phosphate buffer ( $\mathrm{pH} 8.0)$. The absorbance was measured at $\lambda=412 \mathrm{~nm}$ in a 96 -microplate reader. 1\% DMSO and Galantamine were used as positive control and reference respectively. The percentage of cholinesterases inhibition was calculated as follows.

$$
\% \mathrm{AChE} \text { or BChE Inhibition }=\frac{\text { Absorbance of Control }- \text { Absorbance of Test }}{\text { Absorbance of Control }} * 100 \%
$$

\section{High resolution mass spectrometric (HRMS) profiling of metabolites}

Liquid chromatography and mass spectrometry (LCMS) analysis were performed using an HPLC-ESIQTOF-MS instrument on an Agilent 6520 quadrupole time-of-flight (QTOF) mass spectrometer connected with Agilent 1200-HPLC system via Dual electrospray ionization (ESI) interface (Agilent Technologies, USA). $1 \mathrm{mg} / \mathrm{mL}$ stock solution of methanol extract was filtered through a $0.22 \mu \mathrm{m}$ syringe filter. The filtered stock solution was further diluted to $500 \mathrm{ppm}$ using methanol. The prepared dilution was transferred into a high-performance liquid chromatography (HPLC) autosampler vial for LC-MS analysis and $1 \mu \mathrm{L}$ aliquot was injected into the HPLC-ESI-QTOF-MS system. The Mass Hunter software version B.04.00 build 4.0.479.0 (Agilent Technology) was used to analyze chromatogram, mass spectra, exact mass calculation, and prediction of chemical formula of the identified compounds as by Singh et al. [38].

\section{Statistical analysis}

All the experiments were carried out triplicates and data were presented in mean \pm standard deviation (mean $\pm \mathrm{SD})$. Inhibitory concentration at which absorbance is $50 \%\left(\mathrm{IC}_{50}\right)$ values were calculated in MS Excel 2013 by linear regression analysis of percentage inhibitions.

\section{Results}

Antioxidant activities

In our study, crude extracts of B. pacumbis showed considerable antioxidant activities against DPPH and ABTS in all solvent extracts with respect to standard Gallic acid (Table 1). The highest 
Table 1 Antioxidant Activities of B. pacumbis

\begin{tabular}{lll}
\hline Extracting & \multicolumn{1}{l}{$\mathrm{C}_{\mathbf{5 0}}$ Value $(\mu \mathrm{g} / \mathrm{mL})$} \\
\cline { 2 - 3 } Solvents & $\mathrm{DPPH}$ & ABTS \\
\hline Hexane & $194.41 \pm 0.62$ & $100.57 \pm 0.40$ \\
Ethyl Acetate & $30.14 \pm 0.41$ & $17.38 \pm 1.12$ \\
Methanol & $40.87 \pm 0.32$ & $19.03 \pm 2.51$ \\
Water & $98.29 \pm 0.13$ & $44.28 \pm 0.38$ \\
Gallic Acid & $5.12 \pm 0.12$ & $1.96 \pm 0.05$ \\
\hline
\end{tabular}

$I C_{50}$ Inhibitory concentration at which absorbance is $50 \%$

antioxidant was found in ethyl acetate extract against DPPH $\left(\mathrm{IC}_{50}=30.14 \pm 0.41 \mu \mathrm{g} / \mathrm{mL}\right)$ and ABTS $\left(\mathrm{IC}_{50}=17.38 \pm 1.12 \mu \mathrm{g} / \mathrm{mL}\right)$ and least was found in hexane extract against $\mathrm{DPPH} \quad\left(\mathrm{IC}_{50}=194.41 \pm\right.$ $0.62 \mu \mathrm{g} / \mathrm{mL})$ and ABTS $\left(\mathrm{IC}_{50}=100.57 \pm 0.40 \mu \mathrm{g} / \mathrm{mL}\right)$ whereas crude methanol and water extract showed satisfactory inhibitory potential against both DPPH and ABTS.
Alpha-amylase, alpha-glucosidase, and lipase inhibition activity

Our results revealed that crude extracts of $B$. pacumbis in different extracting solvents are potent $\alpha$-amylase and $\alpha$-glucosidase inhibitors (Fig. $1 \mathrm{~A} \& \mathrm{~B}$ ). The highest $\alpha$-amylase inhibition was found in methanol extract $\left(\mathrm{IC}_{50}=14.03 \pm 0.04 \mu \mathrm{g} / \mathrm{mL}\right)$ and least in water extract $\left(\mathrm{IC}_{50}=43.77 \pm 0.54 \mu \mathrm{g} / \mathrm{mL}\right)$. Similarly, highest $\alpha$-glucosidase inhibition was found in methanol extract $\left(\mathrm{IC}_{50}=0.29 \pm 0.00 \mu \mathrm{g} / \mathrm{mL}\right)$ and least in water extract $\left(\mathrm{IC}_{50}=3.54 \pm 0.00 \mu \mathrm{g} / \mathrm{mL}\right)$ and there is no sign of $\alpha$-amylase and $\alpha$-glucosidase inhibitory potential of hexane extract (Table 2). These results indicate that inhibition of $\alpha$-amylase and $\alpha$ glucosidase by the crude methanol extract of $B$. pacumbis is comparable to the standard drug Acarbose. Furthermore, all solvent extracts of B. pacumbis exhibited the lipase inhibitory potential (Fig. $1 \mathrm{C}$, Table 2). The highest lipase inhibition was found in

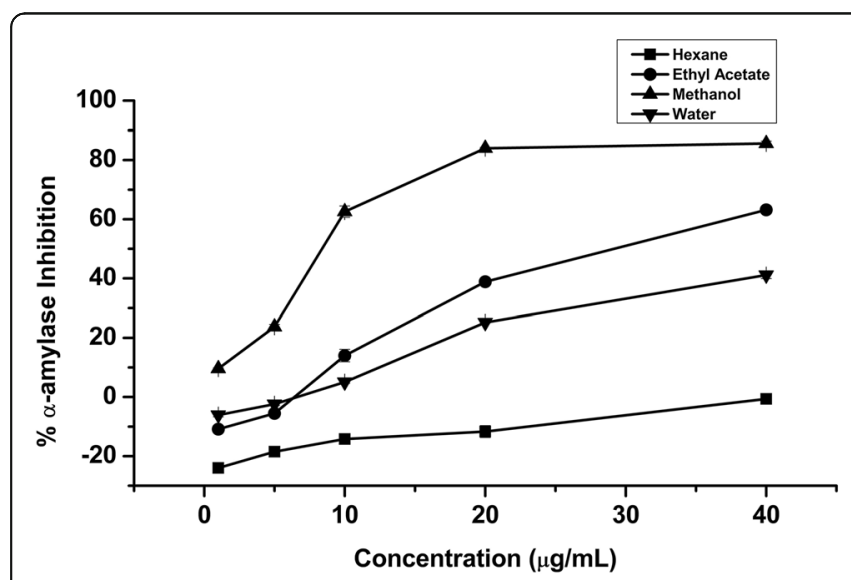

A

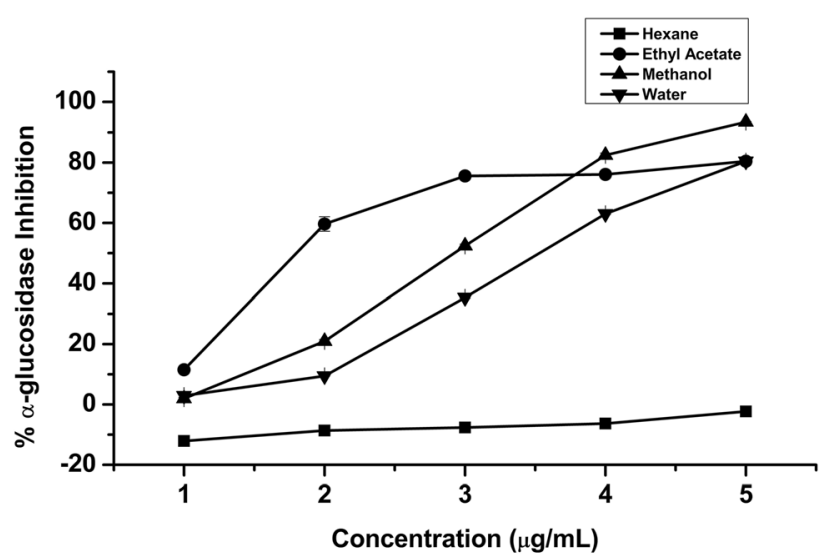

B

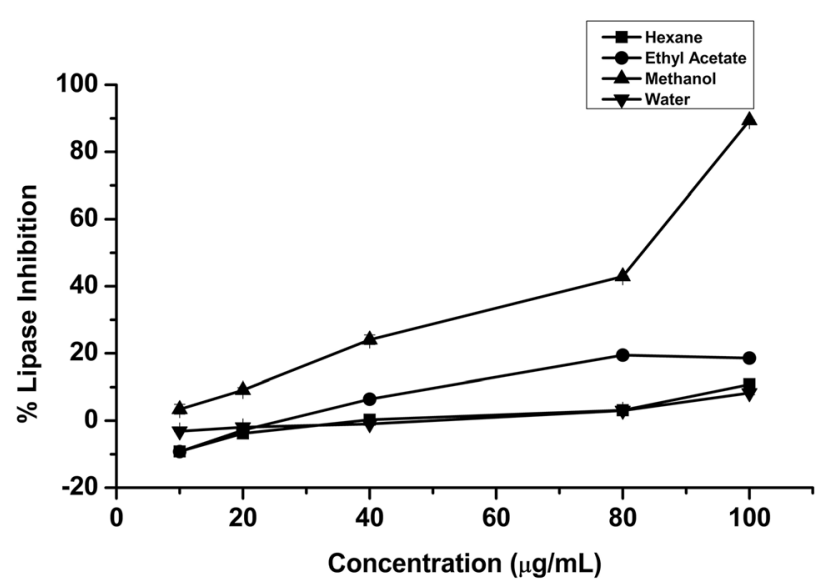

C

Fig. 1 a $a$-amylase Inhibitory Concentration, b a-glucosidase Inhibitory Concentration, c Lipase Inhibitory Concentration of B. pacumbis 
Table 2 Enzymes Inhibition Activities of B. pacumbis

\begin{tabular}{|c|c|c|c|c|c|c|c|}
\hline \multirow{2}{*}{$\begin{array}{l}\text { Extracting } \\
\text { Solvents }\end{array}$} & \multicolumn{7}{|c|}{$\mathrm{IC}_{50}$ Values $(\mu \mathrm{g} / \mathrm{mL})$} \\
\hline & $\boldsymbol{a}$-Amylase & $\boldsymbol{a}$-Glucosidase & Lipase & Tyrosinase & Elastase & AChE & BChE \\
\hline Hexane & $\mathrm{NI}$ & $\mathrm{NI}$ & $447.86 \pm 19.58$ & $\mathrm{NI}$ & $\mathrm{NI}$ & $\mathrm{Nl}$ & $\mathrm{Nl}$ \\
\hline Ethyl Acetate & $29.91 \pm 0.22$ & $2.49 \pm 0.01$ & $121.71 \pm 5.75$ & $280.36 \pm 1.56$ & $174.34 \pm 1.44$ & $36.79 \pm 2.66$ & $14.83 \pm 1.88$ \\
\hline Methanol & $14.03 \pm 0.04$ & $0.29 \pm 0.00$ & $67.26 \pm 0.17$ & $58.25 \pm 1.63$ & $74.00 \pm 3.03$ & $31.52 \pm 0.58$ & $11.69 \pm 0.14$ \\
\hline Water & $43.77 \pm 0.54$ & $3.54 \pm 0.00$ & $445.202 \pm 2.15$ & $168.81 \pm 0.56$ & $\mathrm{Nl}$ & $104.37 \pm 1.88$ & $76.99 \pm 0.37$ \\
\hline Acarbose & $20.12 \pm 0.12$ & $261.23 \pm 9.10$ & - & - & - & - & - \\
\hline Kojic Acid & - & - & - & $18.39 \pm 0.15$ & - & - & - \\
\hline Orlistat & - & - & $431.58 \pm 13.82$ & - & - & - & - \\
\hline Quercetin & - & - & - & - & $101.23 \pm 0.16$ & - & - \\
\hline Galantamine & - & - & - & - & - & $1.09 \pm 0.02$ & $26.27 \pm 1.41$ \\
\hline
\end{tabular}

AChE Acetylcholinesterase, $B C h E$ Butyrylcholinesterase, $N I$ No inhibition, $I C_{50}$ Inhibitory concentration at which absorbance is $50 \%$

crude methanol extract $\left(\mathrm{IC}_{50}=90.53 \pm 0.31 \mu \mathrm{g} / \mathrm{mL}\right)$ and least in hexane extract $\left(\mathrm{IC}_{50}=447.86 \pm 19.58 \mu \mathrm{g} / \mathrm{mL}\right.$ ) which is compared with the standard drug, Orlistat that have an $\mathrm{IC}_{50}$ value of $431.58 \pm 13.82 \mu \mathrm{g} / \mathrm{mL}$.

\section{Tyrosinase and elastase inhibition activity}

Inhibitions of the tyrosinase enzyme somehow lower the excessive production of melanin and then prevent melanogenesis. Therefore, the control of melanogenesis is important to individuals with clinical or cosmetic needs to enhance dermatological protection. Plant-based natural antioxidants are now gaining much emphasis on modern cosmetics to encounter these skin-related complications. B. pacumbis showed higher inhibitory potential against the mushroom tyrosinase in crude methanol extract $\left(\mathrm{IC}_{50}=58.25 \pm 1.63 \mu \mathrm{g} / \mathrm{mL}\right)$ and crude water extract $\left(\mathrm{IC}_{50}=168.81 \pm 0.56 \mu \mathrm{g} / \mathrm{mL}\right)$ with compared to crude ethyl acetate and hexane extract (Fig. 2 A). Kojic acid has greater inhibiting potential as compared to the plant extracts with an $\mathrm{IC}_{50}$ value of $18.39 \pm 0.15 \mu \mathrm{g} / \mathrm{mL}$ (Table 2). In addition, our results revealed the highest elastase inhibition in crude methanol extract followed ethyl acetate extract as an $\mathrm{IC}_{50}$ value of $74.00 \pm 3.03 \mu \mathrm{g} /$ $\mathrm{mL}$ and $174.34 \pm 1.44 \mu \mathrm{g} / \mathrm{mL}$ respectively (Table 2 ). Nevertheless, hexane and water extracts of B. pacumbis did not show any inhibition against elastase (Fig. 2 B).

\section{Acetylcholinesterase and butyrylcholinesterase inhibition activity}

The examined plant extracts showed inhibitory activities against acetylcholinesterase (AChE) as well as butyrylcholinesterase (BChE). The highest $\mathrm{AChE}$ and $\mathrm{BChE}$ inhibition were observed in crude methanol extract of B. pacumbis as an $\mathrm{IC}_{50}$ value of $31.52 \pm 0.58 \mu \mathrm{g} /$ $\mathrm{mL}$ and $11.69 \pm 0.14 \mu \mathrm{g} / \mathrm{mL}$ respectively followed by crude ethyl acetate and water extract (Table 2). The crude ethyl acetate and water extract also possessed the greater inhibitory potential of these enzymes compared with standard drug, Galantamine (Fig. 2 C\&D).

\section{High resolution mass spectrometry analysis}

The chromatogram of methanolic extract of B. pacumbis showed the different mass spectra of the compounds and we analyzed it further for the prediction of chemical formula including the exact mass calculation by Mass Hunter software version B.04.00 build 4.0.479.0 (Agilent Technology) (Fig. 3). Detail of identified compounds with their theoretical and observed mass to charge ratio and errors in parts per million (ppm) in positive ion mode in ESI is presented in Table 3s. The compounds were identified based on the observed MS spectra and also compared with the literature data [39-41]. We observed the presence of flavonoids and phenolic compounds in the crude methanol extract of $B$. pacumbis such as Bergenin $(\mathrm{m} / \mathrm{z}=$ 327.072), Catechin $(\mathrm{m} / \mathrm{z}=289.071)$, Arbutin $(\mathrm{m} / \mathrm{z}=$ 271.082), Gallic acid $(\mathrm{m} / \mathrm{z}=169.014)$, Protocatechuic acid $(\mathrm{m} / \mathrm{z}=153.019)$, Syringic acid $(\mathrm{m} / \mathrm{z}=197.045)$, Hyperoside $(\mathrm{m} / \mathrm{z}=463.088)$, Afzelechin $(\mathrm{m} / \mathrm{z}=273.076)$, Methyl gallate $(\mathrm{m} / \mathrm{z}=183.029)$, Paashaanolactone $(\mathrm{m} / \mathrm{z}=$ 411.129), Astilbin $(\mathrm{m} / \mathrm{z}=449.108)$, Quercetin $(\mathrm{m} / \mathrm{z}=$ 301.034), Kaempferol-7-O-glucoside $(\mathrm{m} / \mathrm{z}=447.093)$, Diosmetin $(\mathrm{m} / \mathrm{z}=299.056)$, Phloretin $(\mathrm{m} / \mathrm{z}=273.076)$, and Morin $(\mathrm{m} / \mathrm{z}=301.035)$ (Fig. $4 \quad \mathrm{~A} \& \mathrm{~B})$.

\section{Discussion}

Plants has been used for medicine from ancient times for the treatment of different human ailments. Antioxidant compounds act as a preventive agent against oxidation process. Antioxidants scavenge free radicals and protect humans against various diseases. Nowadays lots of synthetic molecules with potential enzyme inhibitory tendencies are being used as a food supplement. Although synthetic antioxidants are in use, it might have adverse health effects due to their several side effects [42]. Hence, more researches are being carried out to 


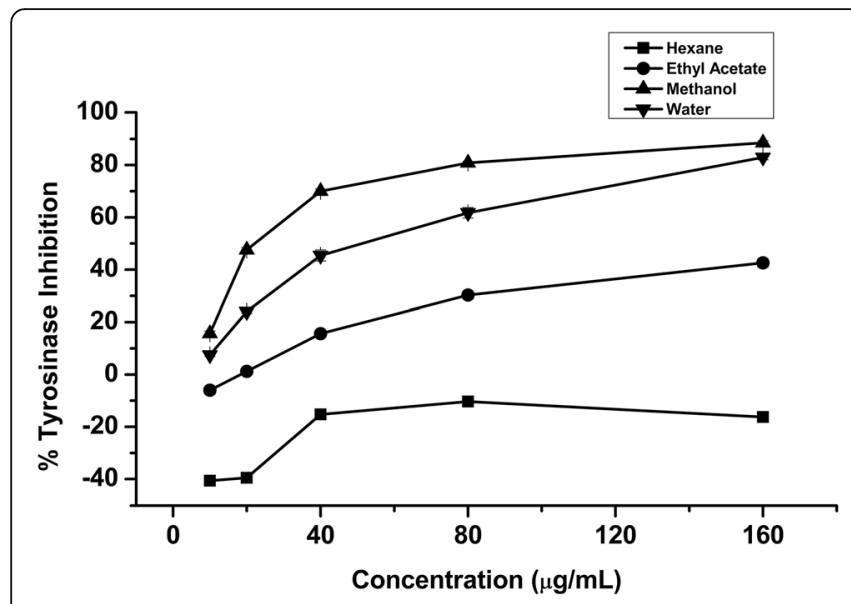

A

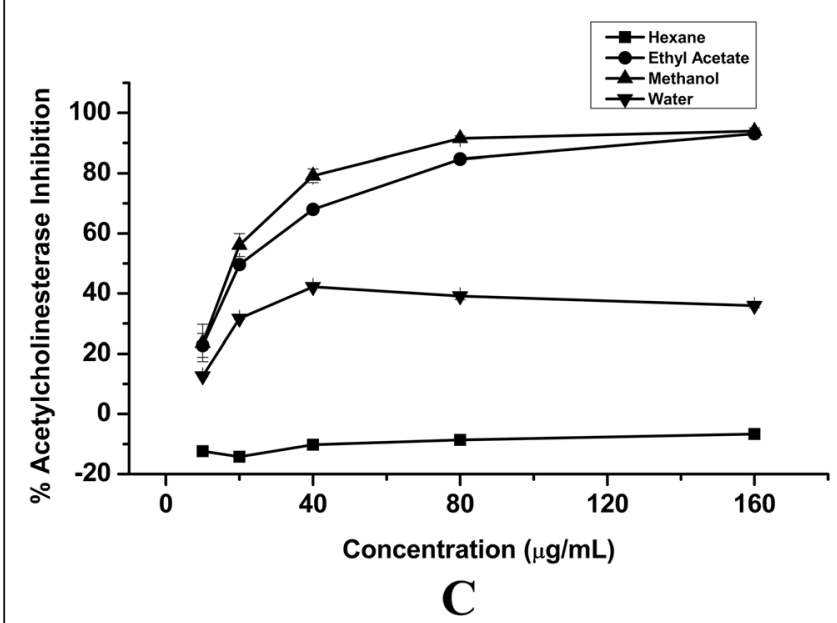

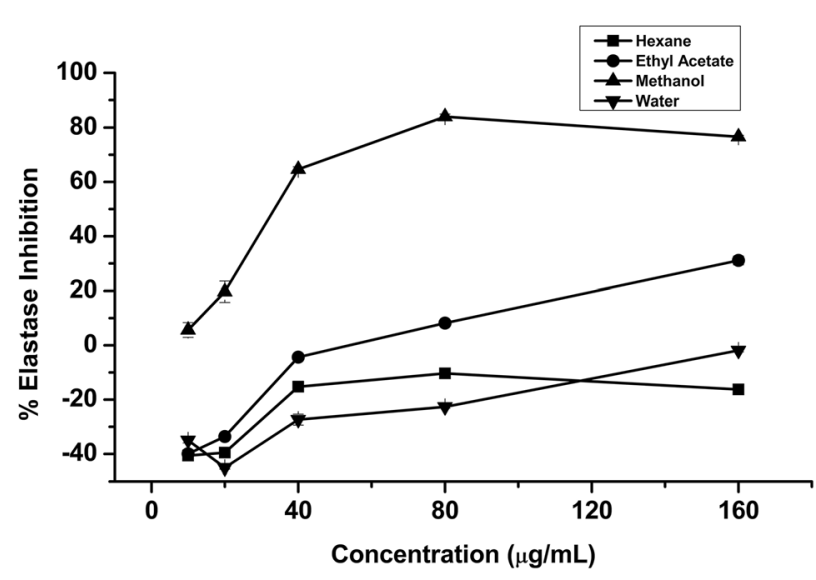

B

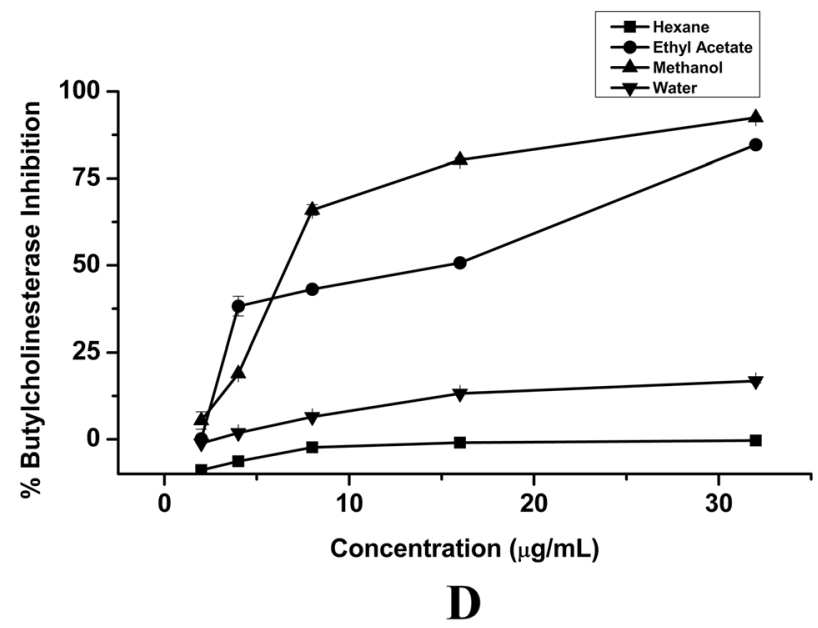

Fig. 2 a Tyrosinase Inhibitory Concentration, b Elastase Inhibitory Concentration, c Acetylcholinesterase Inhibitory Concentration, and d Butyrylcholinesterase Inhibitory Concentration of B. pacumbis

identify the potential natural antioxidant molecules from herbal extract [43]. In this study, B. pacumbis root was extracted with four different solvent hexane, ethyl acetate, methanol, and water. Antioxidant capacities of the solvent extract were analyzed using DPPH and ABTS assay. Results revealed that crude ethyl acetate and methanol extract have the highest antioxidant capacities with the least $\mathrm{IC}_{50}$ values as depicted in results. Furthermore, crude hexane extract showed the lowest antioxidant tendencies as compared to the crude water extract. The results are comparable with reported Bergenia species $[44,45]$. Based on this finding we suggested that different crude extracts of roots of $B$. pacumbis are the considerable source of antioxidant molecules and can be extracted and analyzed further in-vivo for the several health benefits. The different phenolics and flavonoids molecules present in the plant extract might be the source of antioxidant activities [6]. We next examined the plant extracts for their inhibitory potential towards $\alpha$-amylase, $\alpha$-glucosidase, lipase, tyrosinase, elastase, acetylcholinesterase, and butyrylcholinesterase.

Obesity is linked with the abnormal accumulation of fat in the body and causes several health complications such as cardiovascular diseases, cancers, osteoarthritis, hypertension and diabetes [46]. Scientific evidence supported that the person suffering from obesity and diabetes are more prone to the development of cardiovascular disease [47]. It has been proven that medicinal plant and its extract has tendencies to lower the risk of obesity and diabetes by inhibiting the enzymes such as lipase, $\alpha$-amylase, and $\alpha$-glucosidase that are involved in fat and carbohydrates metabolism in the human body. The $\alpha$-amylase and $\alpha$-glucosidase are the carbohydrate hydrolyzing enzyme that breakdown the glycosidic bond and releases glucose, which increases the concentration of glucose in the body and has a negative impact on diabetic patients. The pathogenesis of T2DM is currently accredited to genetics and metabolic 


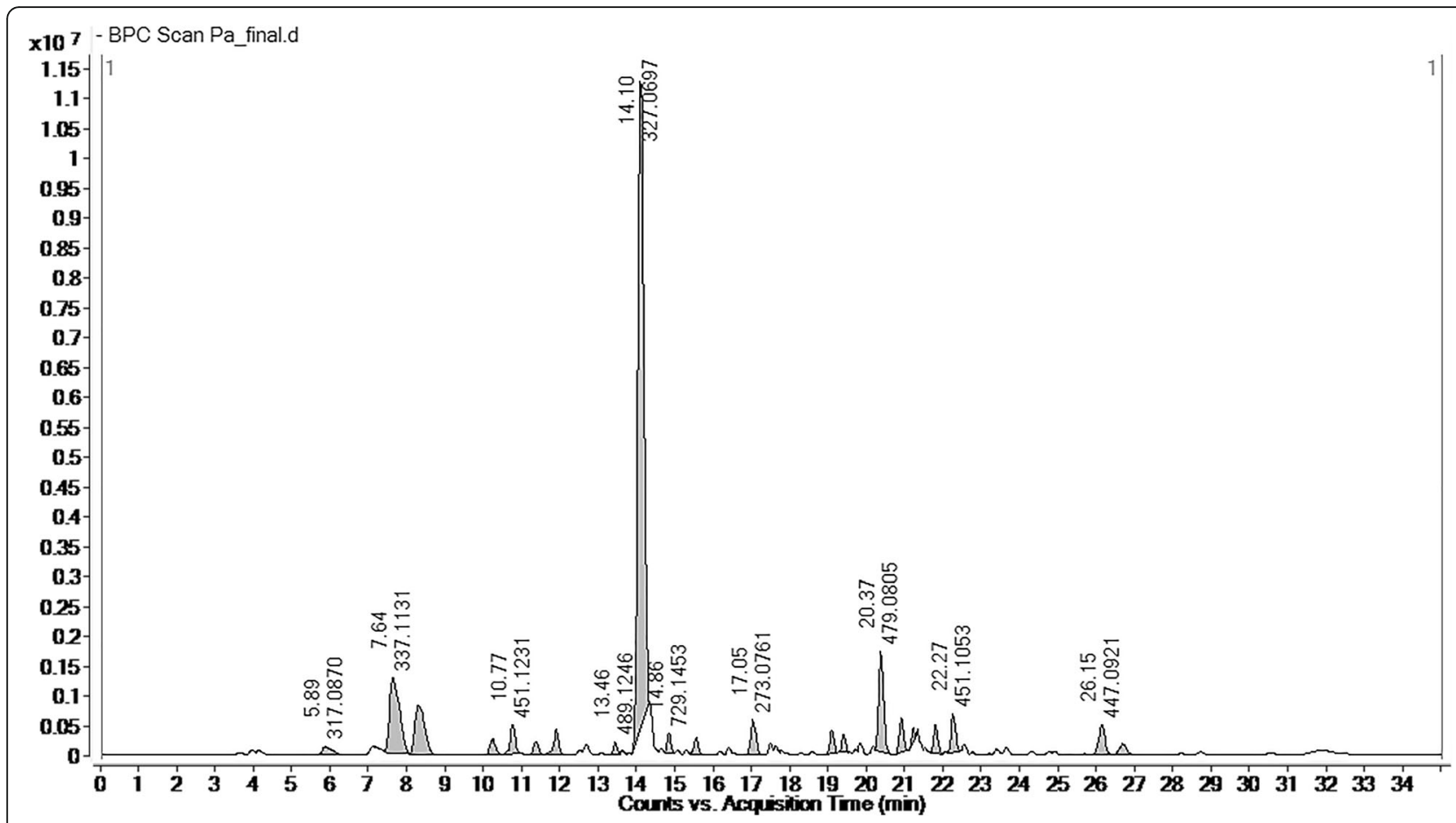

Fig. 3 HRMS Chromatogram for Methanol Extract of B. pacumbis

abnormalities [48] and its treatment with the currently available drugs is still not adequate to prevent long-term diabetic complications [49]. Moreover, human pancreatic lipase is the main enzyme that breaks down dietary fats in the human digestive system $[20,50]$. The commercial anti-obesity drugs have some serious side effects
$[51,52]$ which enforce plant-based remedies of natural choice for the treatment of obesity that considered to have wide variety of natural chemical compounds having diverse structural features to inhibit lipase [53]. Plant extract had tendencies to inhibit the digestive enzyme such as $\alpha$-amylase, $\alpha$-glucosidase, and lipase which made

Table 3 Details on Metabolites Identified by HRMS

\begin{tabular}{|c|c|c|c|c|c|c|c|}
\hline S. No. & Compounds & Molecular Formula & Molecular weight [M] & Measured Mass $(\mathrm{M}-\mathrm{H})^{-}$ & $\begin{array}{l}\text { Observed } \\
\text { Mass }(\mathrm{M}-\mathrm{H})^{-}\end{array}$ & $\begin{array}{l}\text { Retention Time } \\
\text { (minutes) }\end{array}$ & Error (ppm) \\
\hline 1 & Bergenin & $\mathrm{C}_{14} \mathrm{H}_{16} \mathrm{O}_{9}$ & 328.273 & 327.072 & 327.072 & 14.00 & 1.22 \\
\hline 2 & Catechin & $\mathrm{C}_{15} \mathrm{H}_{14} \mathrm{O}_{6}$ & 290.260 & 289.071 & 289.071 & 17.60 & 0.62 \\
\hline 3 & Arbutin & $\mathrm{C}_{12} \mathrm{H}_{16} \mathrm{O}_{7}$ & 272.253 & 271.082 & 271.082 & 5.80 & 0.06 \\
\hline 4 & Gallic acid & $\mathrm{C}_{7} \mathrm{H}_{6} \mathrm{O}_{5}$ & 170.120 & 169.014 & 169.014 & 8.30 & 0.57 \\
\hline 5 & Protocatechuic acid & $\mathrm{C}_{7} \mathrm{H}_{6} \mathrm{O}_{4}$ & 154.121 & 153.019 & 153.019 & 12.50 & 1.25 \\
\hline 6 & Syringic acid & $\mathrm{C}_{9} \mathrm{H}_{10} \mathrm{O}_{5}$ & 198.174 & 197.045 & 197.045 & 12.70 & 1.02 \\
\hline 7 & Hyperoside & $\mathrm{C}_{21} \mathrm{H}_{20} \mathrm{O}_{12}$ & 464.379 & 463.088 & 463.087 & 24.70 & 0.72 \\
\hline 8 & Afzelechin & $\mathrm{C}_{15} \mathrm{H}_{14} \mathrm{O}_{5}$ & 274.272 & 273.076 & 273.076 & 17.10 & 1.93 \\
\hline 9 & Methyl gallate & $\mathrm{C}_{8} \mathrm{H}_{8} \mathrm{O}_{5}$ & 184.150 & 183.029 & 183.029 & 15.70 & 1.91 \\
\hline 10 & Paashaanolactone & $\mathrm{C}_{19} \mathrm{H}_{24} \mathrm{O}_{10}$ & 412.136 & 411.129 & 411.129 & 21.30 & 0.39 \\
\hline 11 & Astilbin & $\mathrm{C}_{21} \mathrm{H}_{22} \mathrm{O}_{11}$ & 450.396 & 449.108 & 449.108 & 17.80 & 1.68 \\
\hline 12 & Quercetin & $\mathrm{C}_{15} \mathrm{H}_{10} \mathrm{O}_{7}$ & 302.236 & 301.035 & 301.034 & 25.70 & 1.82 \\
\hline 13 & Kaempferol-7-O-glucoside & $\mathrm{C}_{21} \mathrm{H}_{20} \mathrm{O}_{11}$ & 448.380 & 447.093 & 447.093 & 26.00 & 0.33 \\
\hline 14 & Diosmetin & $\mathrm{C}_{16} \mathrm{H}_{12} \mathrm{O}_{6}$ & 300.266 & 299.056 & 299.055 & 18.70 & 1.82 \\
\hline 15 & Phloretin & $\mathrm{C}_{15} \mathrm{H}_{14} \mathrm{O}_{5}$ & 274.260 & 273.076 & 273.076 & 19.80 & 0.51 \\
\hline 16 & Morin & $\mathrm{C}_{15} \mathrm{H}_{10} \mathrm{O}_{7}$ & 302.235 & 301.035 & 301.035 & 25.60 & 0.34 \\
\hline
\end{tabular}




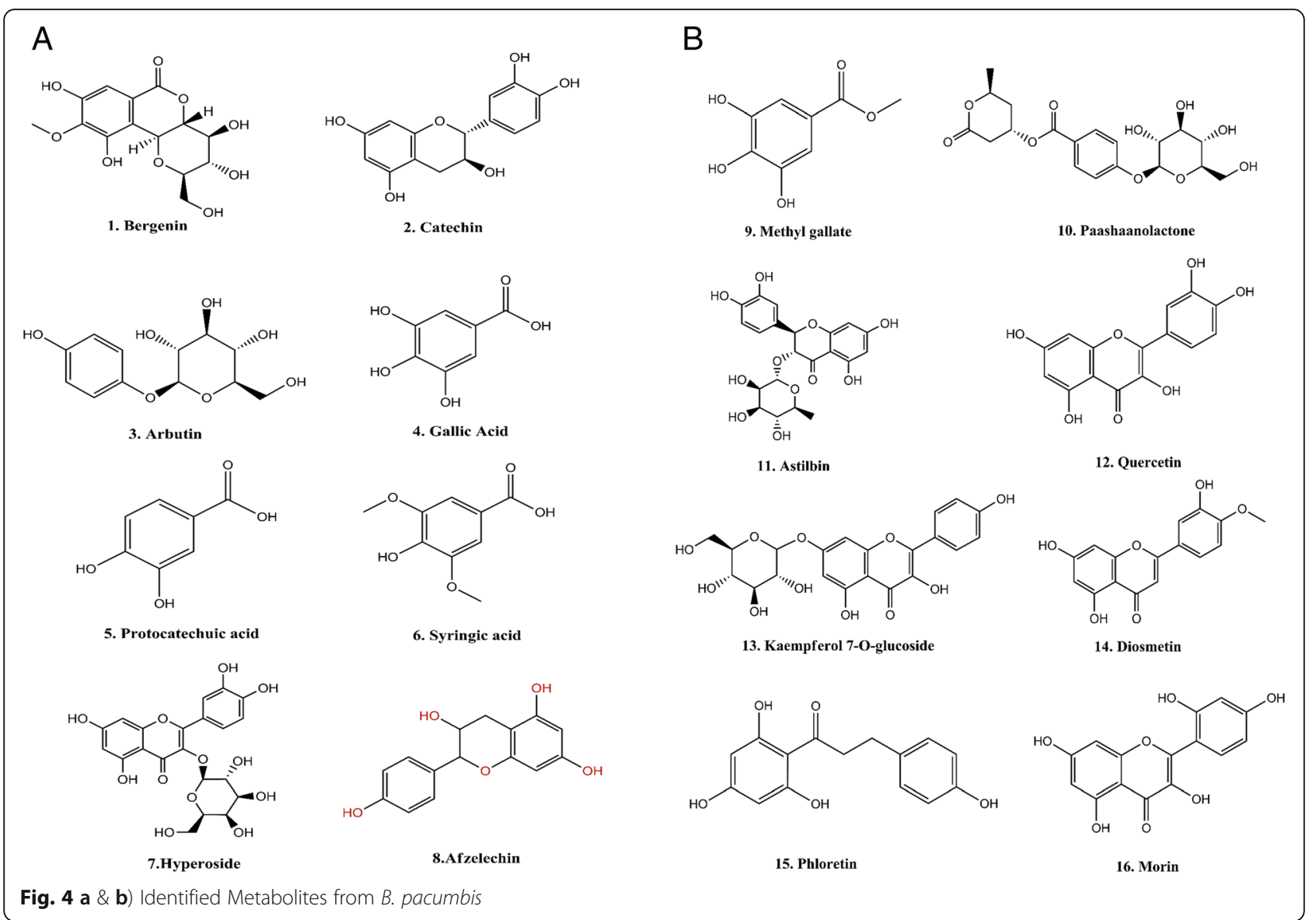

medicinal plant and herbal remedies as alternative source of inhibitor of major enzymes and gaining public interest across the world. Different species of Bergenia and their secondary metabolites are already reported as potent anti-diabetic sources in-vitro and in-vivo [54-57]. Our results revealed that crude extracts of $B$. pacumbis are the inhibitor of these digestive enzymes. The root extract of B. pacumbis showed inhibitory activities towards $\alpha$-amylase, $\alpha$-glucosidase, and lipase. Results revealed that among four analyzed solvent extracts, the crude methanol extract has greater inhibitory activities compared to Acarbose and Orlistat. These results are consistent with the investigation of the different fractions of B. ciliata by Bhandari et al., 2007 [54]. However, hexane extract does not reveal any inhibition against these enzymes. Our finding opens up the possibility of finding potential inhibitors in the methanol extract.

Melanin is an important component which helps in regulating physiology, pathology, and toxicology of several organs such as skin, eyes, and brain [58]. Accumulation of unnecessary levels of epidermal pigmentation causes various dermatological disorders, such as age spots and freckles [59]. Due to the high reactivity of tyrosinase, melanin reacts with amino acids and proteins to enhance the brown color pigmentation in the skin $[60,61]$. Scavenging of ROS and tyrosinase enzyme by natural bioactive molecules might be an option to enhance the whitening of skin color [62]. The generation of ROS by solar ultraviolet (UV) radiation adversely affects skin health by the activation of enzymes such as elastase that degrade extracellular matrix (ECM) proteins in the dermis [63]. Thus, elastase inhibition is a useful approach to prevent skin alterations and premature skin aging. In our observation, crude methanol extract followed by water and ethyl acetate extract of B. pacumbis has tyrosinase inhibitory potential compared to standard drug Kojic acid. In comparison to the lipase, amylase and glucosidase inhibitory potential, crude extracts of $B$. pacumbis revealed comparatively lower inhibitory potential against tyrosinase and elastase. Only crude methanol and ethyl acetate extracts of $B$. pacumbis showed the elastase inhibition compared to standard Quercetin. Whereas, crude water extract does not reveal any inhibition in the given concentration towards elastase enzymes. The presence of arbutin might be the defined source of tyrosinase inhibition from B. pacumbis $[64,65]$. However, the purification of those extracts might enhance the inhibitory potential of $B$. pacumbis on the tyrosinase and elastase. 
In recent years, enzyme inhibitory strategies are considered as one of the most effective strategies in combating global health problems including Alzheimer's diseases $(\mathrm{AD})$ [66]. The natural inhibitors of cholinesterases (ChEs) from the plant origin for the management of cognitive/mental disorders have gained interest due to the presence of polyphenolic compounds such as quercetin, catechin, bergenin, and rutin which have several health benefits $[67,68]$. Aromatic and medicinal plants may have an important role in oxidative stress protection, which are good sources of acetylcholinesterase and butyrylcholinesterase inhibitor to controlling AD [69]. A recent study showed that the different pure isolated metabolites from B. ciliata have potent acetylcholinesterase and butyrylcholinesterase inhibition activity [44]. Our study revealed that crude methanol, ethyl acetate, and water extract of $B$. pacumbis to have great inhibitory potential toward acetylcholinesterase and butyrylcholinesterase. However, hexane extract does not reveal any inhibition towards these enzymes. Remarkably methanol extract has significant inhibitory activities against all enzymes.

The diverse secondary metabolites with ranges of pharmacological significance were isolated and studied from Bergenia species. For example gallic acid, tannic acid, glucose, mucilage, bergenin, stigmasterol, $\beta$ sitosterol, arbutin, phytol, damascenone, 3-methyl-2buten-1-ol, syringic acid, hyperoside, afzelechin, methyl gallate, paashaanolactone, etc. have been isolated from Bergenia ciliata, Bergenia ligulatas, and Bergenia stracheyi till date [7, 70, 71]. Our HRMS data also revealed the presence of diverse secondary metabolites in the methanol extract, which might be the reason behind the higher bioactivities. These secondary metabolites possess marked bioactivities. Enzymes inhibitory tendencies of these extracts may be due to the presence of diverse bioactive molecules such as catechin, bergenin, and many other flavonoids molecules. Bergenin and catechin are the marker compound of Bergenia species which are major bioactive ingredients in the herb-drug [39, 72] and have antioxidant, anti-inflammatory, antiviral, antihyperglycemic, immunostimulant, and antipyretic potential [39, 73]. Phenolic acids such as gallic acid, protocatechuic acid, and ferulic acid are known to inhibit cancer cells [74]. The major compound identified in B. pacumbis were Bergenin, catechin, arbutin, gallic acid, protocatechuic acid, syringic acid, hyperoside, afzelechin, methyl gallate, paashaanolactone, astilbin, quercetin, kaemferol-7-O-glucoside, diosmetin, phloretin, and morin. Most of the compounds identified here are highly abundant in Bergenia species. Arbutin is the great tyrosinase inhibitor [65], morin has great antioxidant and cholinesterases inhibiting potential [44]. Flavonoids like afzelechin and quercetin show antioxidant and anti- diabetic properties [75, 76]. All the identified compounds based on HRMS data were further verified with the literature report i.e. Arbutin, Gallic Acid, Protocatechuic Acid, Bergenin, Catechin and Syringic Acid [39], Hyperoside [77], Afzelechin [78, 79], Methyl Gallate [80], Paashaanolactone [81], Astilbin [82], Quercetin [83], Kaempferol-7-O-glucoside [84, 85], Diosmetin [86], Phloretin [87], and Morin [88]. We firmly believe that presence of phenolic and flavonoids molecules are largely responsible for the bioactivities of B. pacumbis.

\section{Conclusion}

Our study provides a plethora of scientific evidence that the different extracts of $B$. pacumbis from Nepali origin have astonishing potential on inhibiting free radicals as well as enzymes involved in digestion, skin related problems, and neurological disorders compared with the commercially available drugs. The great ability of this plant to inhibit those enzymes is basically due to the presence of active secondary metabolites. Our finding opens up the possibilities in future to identify the potent inhibitory compounds of pharmaceuticals and cosmetics application.

\begin{abstract}
Abbreviations
$\mu \mathrm{g}$ : Microgram; AAAPVN: N-Succinyl-Ala-Ala-p-nitroanilide; ABTS: 2, 2'-Azinobis (3-ethylbenzothiazoline-6-sulfonic acid) diammonium salt;

AChE: Acetylcholinesterase; AD: Alzheimer's disease;

BChE: Butyrylcholinesterase; DM: Diabetes mellitus; DMSO: Dimethyl

sulfoxide; DNSA: 3,5-Dinitrosalicylic acid; DPPH: 2, 2-Diphenyl-1-picrylhydrazyl; DTNB: 5,5'-dithiobis-(2-nitrobenzoic acid); ECM: Extracellular matrix;

ESI: Electrospray ionization; HPLC: High-performance liquid chromatography; HRMS: High resolution mass spectroscopy; $I_{5}$ : Inhibitory concentration at which absorbance is 50\%; KATH: National Herbarium and Plant Laboratory; KOICA: Korea International Cooperation Agency; LCMS: Liquid chromatography and mass spectrometry; L-DOPA: I-3,4-

dihydroxyphenylalanine; M: Molar; mL: Milliliter; mM: Millimolar; NAST: Nepal Academy of Science and Technology; p-NPB: 4-nitrophenyl butyrate; $\mathrm{p}$ NPG: p-Nitrophenyl-a-D-glucopyranoside; PPE: Porcine pancreatic elastase; ppm: Parts per million; QTOF: Quadrupole time-of-flight; ROS: Reactive oxygen species; RSA: Radical scavenging activity; U: Units; UV: Ultraviolet
\end{abstract}

\section{Acknowledgements}

We are thankful to National Herbarium and Plant Laboratory (KATH), Lalitpur, Nepal for the plant identification and authorization. We are also grateful to Nepal Academy of Science and Technology (NAST), Lalitpur, Nepal for the laboratory facility.

\section{Authors' contributions}

SN has collected the plant materials, BPP, SPP, and KA designed the work. SPP, BPP and KP performed the laboratory works, data generation, and data authentication. SPP and BPP wrote and revised the manuscript. SPP and BPP contributed equally to this work. The author(s) read and approved the final manuscript.

\section{Funding}

This research work was funded by H-Plant Private Limited, through the grant support (2012-2017) from Korea International Cooperation Agency (KOICA). The funding source has provided the field collected plant materials for analysis and had no role in study design, data collection and analysis, data interpretation and writing the manuscript. 


\section{Availability of data and materials}

The datasets used and/ or analyzed during the current study available from the corresponding author on reasonable request.

\section{Ethics approval and consent to participate}

Not applicable.

\section{Consent for publication}

Not applicable.

\section{Competing interests}

Authors declare that they have no competing interests.

\section{Author details}

'Department of Chemical Science and Engineering, Kathmandu University, PO Box No. 6250, Dhulikhel, Kavre, Nepal. ${ }^{2} \mathrm{H}$-plant Private Limited, Sanepa, Lalitpur, Nepal.

Received: 17 March 2020 Accepted: 16 June 2020

Published online: 26 June 2020

\section{References}

1. Zhao J, Liu J, Zhang X, et al. Chemical composition of the volatiles of three wild Bergenia species from western China. Flavour Fragrance J. 2006;21(3): $431-4$.

2. Rokaya MB, Münzbergová Z, Timsina B. Ethnobotanical study of medicinal plants from the Humla district of western Nepal. J Ethnopharmacol. 2010; 130(3):485-504.

3. Ruby K, Sharma S, Chauhan R, et al. In-vitro antioxidant and hemorrhoidal potential of hydroethanolic leaf extracts of Bergenia ciliata, Bergenia ligulata and Bergenia stracheyi. Asian J Plant Sci Res. 2015;5:34-46.

4. Kumar V, Tyagi D. Review on phytochemical, ethnomedical and biological studies of medically useful genus Bergenia. Int J Curr Microbiol App Sci. 2013;2(5):328-34

5. Kraujalienè V, Pukalskas A, Kraujalis P, et al. Biorefining of Bergenia crassifolia L. roots and leaves by high pressure extraction methods and evaluation of antioxidant properties and main phytochemicals in extracts and plant material. Ind Crop Prod. 2016;89:390-8.

6. Ahmad M, Butt MA, Zhang G, et al. Bergenia ciliata: a comprehensive review of its traditional uses, phytochemistry, pharmacology and safety. Biomed Pharmacother. 2018;97:708-21.

7. Chauhan R, Ruby K, Dwivedi J. Secondary metabolites found in Bergenia species: a compendious review. Int J Pharm Pharm Sci. 2013;15:17.

8. Patel D, Patel K, Kumar R, et al. Pharmacological and analytical aspects of bergenin: a concise report. Asian Pac J Trop Dis. 2012;2(2):163-7.

9. Uddin G, Sadat A, Siddiqui BS. Comparative antioxidant and antiplasmodia activities of 11-O-galloylbergenin and bergenin isolated from Bergenia ligulata. Trop Biomed. 2014:31(1):143-8.

10. Aggarwal D, Kaushal R, Kaur T, et al. The most potent antilithiatic agent ameliorating renal dysfunction and oxidative stress from Bergenia ligulata rhizome. J Ethnopharmacol. 2014;158:85-93.

11. DeFronzo RA. Pathogenesis of type 2 diabetes mellitus. Med Clin. 2004; 88(4):787-835.

12. Elbashir SMI, Devkota HP, Wada M, et al. Free radical scavenging, $a$ glucosidase inhibitory and lipase inhibitory activities of eighteen Sudanese medicinal plants. BMC Complementary Altern Med. 2018;18(1):282.

13. Subramanian R, Asmawi MZ, Sadikun A. In vitro a-glucosidase and aamylase enzyme inhibitory effects of Andrographis paniculata extract and andrographolide. Acta Biochim Pol. 2008:55(2):391-8.

14. Nair SS, Kavrekar V, Mishra A. In vitro studies on alpha amylase and alpha glucosidase inhibitory activities of selected plant extracts. Eur J Exp Biol. 2013;3(1):128-32

15. Bhat M, Zinjarde SS, Bhargava SY, et al. Antidiabetic Indian plants: a good source of potent amylase inhibitors. Evidence-Based Complementary Altern Med. 2011;2011:810207.

16. Doak CM. The world is fat: the fads, trends, policies and products that are fattening the human race, Barry Popkin, (229 pages) Price: USA \$24.95, ISBN 978-1-58333-313-6. Economics Human Biol. 2009:7(2):265-6.

17. Ordovas JM, Shen J. Gene-environment interactions and susceptibility to metabolic syndrome and other chronic diseases. J Periodontol. 2008;79: 1508-13.
18. Mohamed GA, Ibrahim SR, Elkhayat ES, et al. Natural anti-obesity agents. Bull Fac Pharm. (Cairo Univ.) 2014:52(2):269-284.

19. Trigueros $L$, Peña $S$, Ugidos $A$, et al. Food ingredients as anti-obesity agents: a review. Crit Rev Food Sci Nutr. 2013:53(9):929-42.

20. Buchholz T, Melzig MF. Medicinal plants traditionally used for treatment of obesity and diabetes mellitus-screening for pancreatic lipase and a-amylase inhibition. Phytother Res. 2016;30(2):260-6.

21. Singla P, Bardoloi A, Parkash AA. Metabolic effects of obesity: a review. World J Diabetes. 2010;1(3):76.

22. Tang J, Zhou J, Tang Q, et al. A new TLC bioautographic assay for qualitative and quantitative estimation of lipase inhibitors. Phytochem Anal. 2016;27(1):5-12.

23. Maqsood M, Ahmed D, Atique I, et al. Lipase inhibitory activity of Lagenaria siceraria fruit as a strategy to treat obesity. Asian Pac J Trop Med. 2017;10(3): 305-10.

24. Galván I, Solano F. Melanin chemistry and the ecology of stress. Physiol Biochem Zool. 2015;88(3):352-5.

25. Song $\mathrm{K}-\mathrm{K}$, Huang $\mathrm{H}$, Han $\mathrm{P}$, et al. Inhibitory effects of cis-and trans-isomers of 3,5-dihydroxystilbene on the activity of mushroom tyrosinase. Biochem Biophys Res Commun. 2006;342(4):1147-51.

26. Chang T-S. An updated review of tyrosinase inhibitors. Int J Mol Sci. 2009; 10(6):2440-75.

27. Kim Y-J, Uyama H, Kobayashi S. Inhibition effects of (+)-catechinaldehyde polycondensates on proteinases causing proteolytic degradation of extracellular matrix. Biochem Biophys Res Commun. 2004;320(1):256-61.

28. Baylac S, Racine P. Inhibition of human leukocyte elastase by natural fragrant extracts of aromatic plants. Int J Aromather. 2004;14(4):179-82.

29. Melzig M, Löser B, Ciesielski S. Inhibition of neutrophil elastase activity by phenolic compounds from plants. Die Pharmazie. 2001;56(12):967-70.

30. Siedle B, Cisielski S, Murillo R, et al. Sesquiterpene lactones as inhibitors of human neutrophil elastase. Bioorg Med Chem. 2002;10(9):2855-61.

31. Nordberg A, Ballard C, Bullock R, et al. A review of butyrylcholinesterase as a therapeutic target in the treatment of Alzheimer's disease. Prim Care Companion CNS Disord. 2013;15(2):PCC.12r01412.

32. Jha BN, Shrestha M, Pandey DP, et al. Investigation of antioxidant, antimicrobial and toxicity activities of lichens from high altitude regions of Nepal. BMC Complementary Altern Med. 2017;17(1):282.

33. Liyanaarachchi GD, Samarasekera JKRR, Mahanama KRR, et al. Tyrosinase, elastase, hyaluronidase, inhibitory and antioxidant activity of Sri Lankan medicinal plants for novel cosmeceuticals. Ind Crop Prod. 2018;111:597-605.

34. Wickramaratne $\mathrm{MN}$, Punchihewa J, Wickramaratne D. In-vitro alpha amylase inhibitory activity of the leaf extracts of Adenanthera pavonina. BMC Complementary Altern Med. 2016;16(1):466

35. Spínola V, Pinto J, Castilho PC. Hypoglycemic, anti-glycation and antioxidant in vitro properties of two Vaccinium species from Macaronesia: a relation to their phenolic composition. J Funct Foods. 2018;40:595-605.

36. Di Petrillo A, González-Paramás AM, Era B, et al. Tyrosinase inhibition and antioxidant properties of Asphodelus microcarpus extracts. BMC Complementary Altern Med. 2016;16(1):453.

37. Samaradivakara SP, Samarasekera R, Handunnetti SM, et al. Cholinesterase, protease inhibitory and antioxidant capacities of Sri Lankan medicinal plants. Ind Crop Prod. 2016;83:227-34

38. Singh A, Kumar S, Bajpai V, et al. Structural characterization of flavonoid Cand O-glycosides in an extract of Adhatoda vasica leaves by liquid chromatography with quadrupole time-of-flight mass spectrometry. Rapid Commun Mass Spectrom. 2015;29(12):1095-106.

39. Pandey R, Kumar B, Meena B, et al. Major bioactive phenolics in Bergenia species from the Indian Himalayan region: Method development, validation and quantitative estimation using UHPLC-QqQLIT-MS/MS. PLoS ONE. 2017; 12(7):e0180950.

40. Lee JS, Kim DH, Liu KH, et al. Identification of flavonoids using liquid chromatography with electrospray ionization and ion trap tandem mass spectrometry with an MS/MS library. Rapid Commun Mass Spectrom. 2005; 19(23):3539-48.

41. Gu C, Howell K, Dunshea FR, et al. Lc-esi-qtof/ms characterisation of phenolic acids and flavonoids in polyphenol-rich fruits and vegetables and their potential antioxidant activities. Antioxidants. 2019:8(9):405.

42. Ito N, Hirose M, Fukushima S, et al. Studies on antioxidants: their carcinogenic and modifying effects on chemical carcinogenesis. Food Chem Toxicol. 1986;24(10-11):1071-82. 
43. Politeo O, Bektašević M, Carev I, et al. Phytochemical composition, antioxidant potential and cholinesterase inhibition potential of extracts from Mentha pulegium L. Chem Biodivers. 2018;15(12):e1800374.

44. Zafar R, Ullah H, Zahoor M, et al. Isolation of bioactive compounds from Bergenia ciliata (haw.) Sternb rhizome and their antioxidant and anticholinesterase activities. BMC Complementary Altern Med. 2019; 19(1):296

45. Rajkumar V, Guha G, Kumar RA, et al. Evaluation of Antioxidant Activities of Bergenia ciliata Rhizome. Rec Nat Prod. 2010;4(1):38-48.

46. Wright E Jr, Scism-Bacon J, Glass L. Oxidative stress in type 2 diabetes: the role of fasting and postprandial glycaemia. Int J Clin Pract. 2006; 60(3):308-14.

47. Quan NV, Xuan TD, Tran H-D, et al. Antioxidant, a-amylase and aGlucosidase inhibitory activities and potential constituents of Canarium tramdenum bark. Molecules. 2019;24(3):605.

48. Wu J, Fang Xa, Yuan Y, et al. UPLC/Q-TOF-MS profiling of phenolics from Canarium pimela leaves and its vasorelaxant and antioxidant activities. Rev Bras Farmacogn 2017;27(6):716-723.

49. Pandey A, Tripathi P, Pandey R, et al. Alternative therapies useful in the management of diabetes: a systematic review. J Pharm BioAllied Sci. 2011; 3(4):504.

50. Winkler F, d'Arcy A, Hunziker W. Structure of human pancreatic lipase. Nature. 1990;343(6260):771

51. Kang JG, Park C-Y. Anti-obesity drugs: a review about their effects and safety. Diabetes Metab J. 2012;36(1):13-25.

52. Napier S, Thomas M. 36 year old man presenting with pancreatitis and a history of recent commencement of orlistat case report. Nutr J. 2006; 5(1):19.

53. Seyedan A, Alshawsh MA, Alshagga MA, et al. Medicinal plants and their inhibitory activities against pancreatic lipase: a review. Evidence-Based Complementary Altern Med. 2015;2015.

54. Bhandari MR, Jong-Anurakkun N, Hong G, et al. $\alpha$-Glucosidase and $\alpha$ amylase inhibitory activities of Nepalese medicinal herb Pakhanbhed (Bergenia ciliata, haw.). Food Chem. 2008;106(1):247-52.

55. Matsui T, Tanaka T, Tamura S, et al. a-Glucosidase inhibitory profile of catechins and theaflavins. J Agric Food Chem. 2007:55(1):99-105.

56. Wan $S B, C$ hen D, Dou QP, et al. Study of the green tea polyphenols catechin-3-gallate (CG) and epicatechin-3-gallate (ECG) as proteasome inhibitors. Bioorg Med Chem. 2004;12(13):3521-7.

57. Saijyo J, Suzuki Y, Okuno Y, et al. a-Glucosidase inhibitor from Bergenia ligulata. J Oleo Sci. 2008;57(8):431-5.

58. Bonaventure J, Domingues MJ, Larue L. Cellular and molecular mechanisms controlling the migration of melanocytes and melanoma cells. Pigm Cell Melanoma Res. 2013;26(3):316-25

59. Thanigaimalai P, Le Hoang TA, Lee K-C, et al. Structural requirement (s) of Nphenylthioureas and benzaldehyde thiosemicarbazones as inhibitors of melanogenesis in melanoma B 16 cells. Bioorg Med Chem Lett. 2010;20(9): 2991-3

60. K-i N, Kubo I. Identification of oxidation product of arbutin in mushroom tyrosinase assay system. Bioorg Med Chem Lett. 2003;13(14):2409-12.

61. Matsuura R, Ukeda H, Sawamura M. Tyrosinase inhibitory activity of citrus essential oils. J Agric Food Chem. 2006;54(6):2309-13.

62. Wittenauer J, Mäckle S, Sußmann D, et al. Inhibitory effects of polyphenols from grape pomace extract on collagenase and elastase activity. Fitoterapia. 2015;101:179-87.

63. Rittié L, Fisher GJ. UV-light-induced signal cascades and skin aging. Ageing Res Rev. 2002;1(4):705-20.

64. Lim $Y$-J, Lee $E H$, Kang $T H$, et al. Inhibitory effects of arbutin on melanin biosynthesis of $a$-melanocyte stimulating hormone-induced hyperpigmentation in cultured brownish Guinea pig skin tissues. Arch Pharm Res. 2009;32(3):367-73.

65. Tůmová L, Dolečková I, Hendrychová H, et al. Arbutin Content and Tyrosinase Activity of Bergenia Extracts. Nat Prod Commun. 2017;12(4): $1934578 \times 1701200422$.

66. Zengin G. A study on in vitro enzyme inhibitory properties of Asphodeline anatolica: new sources of natural inhibitors for public health problems. Ind Crop Prod. 2016;83:39-43.

67. Ademosun AO, Oboh G, Bello F, et al. Antioxidative properties and effect of quercetin and its glycosylated form (Rutin) on acetylcholinesterase and butyrylcholinesterase activities. J Evidence-Based Complementary Altern Med. 2016;21(4):NP11-7.
68. Nwanna E, Oyeleye S, Ogunsuyi O, et al. In vitro neuroprotective properties of some commonly consumed green leafy vegetables in southern Nigeria. NFS J. 2016;2:19-24.

69. Arantes S, Piçarra A, Candeias F, et al. Antioxidant activity and cholinesterase inhibition studies of four flavouring herbs from Alentejo. Nat Prod Res. 2017 31(18):2183-7

70. Rajkumar V, Guha G, Kumar RA. Anti-neoplastic activities of Bergenia ciliata rhizome. J Phar Res. 2011;4(2):443-5.

71. Bibi Y, Nisa S, Chaudhary FM, et al. Antibacterial activity of some selected medicinal plants of Pakistan. BMC Complementary Altern Med. 2011;11(1): 52.

72. Dhalwal $K$, Shinde $V$, Biradar $Y$, et al. Simultaneous quantification of bergenin, catechin, and gallic acid from Bergenia ciliata and Bergenia ligulata by using thin-layer chromatography. J Food Compos Anal. 2008;21(6):496500.

73. Pushpalatha HB, Pramod K, Devanathan R, et al. Use of bergenin as an analytical marker for standardization of the polyherbal formulation containing Saxifraga ligulata. Pharmacogn Mag. 2015;11(Suppl 1):S60.

74. Faried A, Kurnia D, Faried L, et al. Anticancer effects of gallic acid isolated from Indonesian herbal medicine, Phaleria macrocarpa (Scheff.) Boerl, on human cancer cell lines. Int J Oncol. 2007;30(3):605-13.

75. Roselli M, Lentini G, Habtemariam S. Phytochemical, antioxidant and anti-aglucosidase activity evaluations of Bergenia cordifolia. Phytother Res. 2012; 26(6):908-14.

76. Rauf A, Uddin G, Siddiqui BS, et al. Antipyretic and antinociceptive activity of Diospyros lotus L. in animals. Asian Pac J Trop Biomed. 2014;4:S382-6.

77. Zhou D, Jin Y, Yao F, et al. Validated LC-MS/MS method for the simultaneous determination of hyperoside and 2"-O-galloylhyperin in rat plasma: application to a pharmacokinetic study in rats. Biomed Chromatogr. 2014;28(8):1057-63.

78. Ben Said R, Hamed Al, Mahalel UA, et al. Tentative characterization of polyphenolic compounds in the male flowers of Phoenix dactylifera by liquid chromatography coupled with mass spectrometry and DFT. Int J Mol Sci. 2017;18(3):512.

79. Reddy UDC, Chawla AS, Deepak M, et al. High pressure liquid chromatographic determination of bergenin and (+)-afzelechin from different parts of Paashaanbhed (Bergenia ligulata yeo). Phytochem Anal Int J Plant Chem Biochem Tech. 1999;10(1):44-7.

80. Jiamboonsri $P$, Pithayanukul $P$, Bavovada $R$, et al. A validated liquid chromatography-tandem mass spectrometry method for the determination of methyl gallate and pentagalloyl glucopyranose: application to pharmacokinetic studies. J Chromatogr B. 2015;986:12-7.

81. Chandrareddy UD, Chawla AS, Mundkinajeddu D, et al. Paashaanolactone from Bergenia ligulata. Phytochemistry. 1998;47(5):907-9.

82. Dong L, Zhu J, Du H, et al. Astilbin from Smilax glabra Roxb. Attenuates inflammatory responses in complete Freund's adjuvant-induced arthritis rats. Evidence-Based Complementary Altern Med. 2017;2017:8246420.

83. Kumar S, Singh A, Kumar B. Identification and characterization of phenolics and terpenoids from ethanolic extracts of Phyllanthus species by HPLC-ESIQTOF-MS/MS. J Pharm Anal. 2017;7(4):214-22.

84. Yamagaki $T$, Watanabe $T$, Tanaka $M$, et al. Laser-induced hydrogen radical removal in UV MALDI-MS allows for the differentiation of flavonoid monoglycoside isomers. J Am Soc Mass Spectrom. 2013;25(1):88-94.

85. Srivastava N, Srivastava A, Srivastava S, et al. Simultaneous quantification of syringic acid and kaempferol in extracts of Bergenia species using validated high-performance thin-layer chromatographic-densitometric method. J Chromatogr Sci. 2016;54(3):460-5.

86. Brito A, Ramirez JE, Areche C, et al. HPLC-UV-MS profiles of phenolic compounds and antioxidant activity of fruits from three Citrus species consumed in northern Chile. Molecules. 2014;19(11):17400-21.

87. Lijia X, Guo J, Chen Q, et al. Quantitation of phlorizin and phloretin using an ultra high performance liquid chromatography-electrospray ionization tandem mass spectrometric method. J Chromatogr B. 2014;960:67-72.

88. Hussain J, Ali L, Khan AL, et al. Isolation and bioactivities of the flavonoids morin and morin-3-O-B-D-glucopyranoside from Acridocarpus orientalis-a wild Arabian medicinal plant. Molecules. 2014;19(11):17763-72.

\section{Publisher's Note}

Springer Nature remains neutral with regard to jurisdictional claims in published maps and institutional affiliations. 